Jpn. J. Med. Sci. Biol., 50, 133 - 150, 1997

\title{
RAPID AND HIGHLY SENSITIVE ENZYME IMMUNOASSAY FOR QUANTITATIVE DETERMINATION OF TETRODOTOXIN
}

\author{
Kentaro KAWATSU, Yonekazu HAMANO, Tomoko YODA, \\ Yoshitake TERANO1 and Tadayoshi SHIBATA
}

Department of Food Microbiology, Osaka Prefectural Institute of Public Health, Nakamichi 1-3-69, Higashinari-ku, Osaka 537, and 1Department of Bacteriology, Osaka City University Medical School, 1-5-7 Asahi-machi, Abeno-ku, Osaka 545

(Received August 12, 1997. Accepted October 28, 1997)

SUMMARY: A monoclonal antibody against tetrodotoxin (TTX) was obtained from Balb/c mice immunized with TTX-bovine serum albumin (BSA) conjugate. The monoclonal antibody was highly specific for TTX and had no cross-reaction to tetrodonic acid, which is a TTX derivative, or gonyautoxins, although a minor cross-reaction to anhydro-tetrodotoxin was observed. The monoclonal antibody neutralized the lethal activity of TTX. By using the monoclonal antibody, a rapid and highly sensitive competitive enzyme immunoassay (EIA) for quantitative analysis of TTX was developed. By the competitive EIA system, TTX can be determined quantitatively in about $30 \mathrm{~min}$ ( $90 \mathrm{~min}$ are required if the time for preparation of the solid-phase antigen was included), and the working range for quantitative analysis of TTX was $2-100 \mathrm{ng} / \mathrm{ml}$. In recovery tests and examinations of TTX samples, results of the mouse bioassay and EIA analyses correlated well $(r=0.987)$. Moreover, it was demonstrated that low concentrations of TTX, which could not be detected by the mouse bioassay, could be determined quantitatively by the competitive EIA.

\section{INTRODUCTION}

TTX is one of the most potent neurotoxins and blocks sodium ion channels responsibe for nerve and muscle excitability $(1,2)$. TTX is found in various ani-

川津健太郎·濱野米一·依田知子·柴田忠良 (大阪府立公衆衛生研究所食品衛生部食品 細菌課 大阪市東成区中道1-3-69)

寺野由剛(大阪市立大学医学部細菌学教室 大阪市阿部野区旭町1-5-7) 
mals including puffer fish and some shellfish (3-14) and causes paralytic poisoning and occasional deaths in humans through ingestion $(15,16)$. It has been considered that TTX is originally produced by marine bacteria and subsequently distributed widely in various marine organisms (17-23). It has also been reported that a small amount of TTX is found in cultured puffer fish which are originally nontoxic (24). Therefore, it is very important to monitor closely TTX in edible puffer fish including cultured ones and other marine products including shellfish.

Mouse bioassay and fluorometric high performance liquid chromatography (HPLC) have been the main methods for determination of TTX (25-28). The mouse bioassay has been used as an official method for the quantification of TTX in Japan (25), but it has a low sensitivity. In addition, the bioassay requires also the continuous supply, maintenance and control of mice. On the other hand, the fluorometric HPLC has a high sensitivity (26-28) but an insufficient specificity (29). This method requires cleanup of samples and very expensive instruments (27). In contrast, it is accepted that the competitive EIA has a high specificity and sensitivity and requires no cleanup of samples. Therefore, EIA systems for some marine toxins such as saxitoxin, ciguatoxin and okadaic acid have been developed (30-35). Recently, there have been a few reports on competitive EIA for TTX (3638); however, these EIA systems for TTX were either of a low sensitivity (36) or required a long time for determination of TTX in comparison with the mouse bioassay $(37,38)$. In these EIA systems, either an antibody against tetrodonic acid, a TTX derivative (36), or that obtained from mice immunized with TTX-keyhole limpet hemocyanin $(\mathrm{KLH})$ conjugate $(37,38)$ was used. However, tetrodonic acid is very different in chemical structure from TTX (Fig. 1) and it has been reported that the antibody obtained from the mice immunized with TTX-KLH conjugate had a low affinity for TTX (39).

Thus, we, using TTX-BSA as an immunogen, attempted to produce a monoclonal antibody with high affinity against TTX and, using the monoclonal antibody, to develop a rapid and highly sensitive competitive EIA for quantitative analysis of TTX. 


\section{MATERIALS AND METHODS}

TTX: TTX (crystaline 3X) was purchased from Sankyo Co. Ltd. (Tokyo) as the standard for the competitive EIA and from Wako Pure Chemical Industries (Osaka) for preparation of TTX-protein conjugate and recovery tests.

Preparation of TTX-protein conjugate: TTX was conjugated to bovine serum albumin (BSA, Sigma Chemical Co., St. Louis, MO) and ovalbumin (OVA, Sigma) by the method of Johnson et al. (40) with some modifications.

(a) Preparation of TTX-BSA conjugate. Five milligrams of BSA was dissolved in $0.4 \mathrm{ml}$ of $0.01 \mathrm{M}$ phosphate buffer (PB, $\mathrm{pH}$ 7.6). To this were added 0.25 mg of TTX and $0.1 \mathrm{ml}$ of $2.5 \%$ formaldehyde. After incubation for $72 \mathrm{hr}$ at $25 \mathrm{C}$ and then for $12 \mathrm{hr}$ at $4 \mathrm{C}$, the mixture was loaded onto a PD-10 column (Pharmacia Biotech., Uppsala, Sweden) equilibrated with $0.01 \mathrm{M}$ PB. After eluting the mixture with $0.01 \mathrm{M} \mathrm{PB}$, the protein-containing portion $(3.5 \mathrm{ml})$ was collected.

(b) Preparation of TTX-OVA conjugate. Five milligrams of OVA was dissolved in $0.4 \mathrm{ml}$ of $0.01 \mathrm{M} \mathrm{PB}$. To this were added $0.5 \mathrm{mg}$ of TTX and $0.1 \mathrm{ml}$ of $2.5 \%$ formaldehyde. The remaining steps were the same as those described above.

Immunization and somatic cell fusion: TTX-BSA conjugate $(1 \mathrm{mg} / \mathrm{ml}$ in 0.01 $\mathrm{M} \mathrm{PB}$ ) was used as the immunogen. Six female BALB/c mice (SPF grade, 7 weeks old, Japan SLC, Inc., Shizuoka, Japan) were immunized by ip injection with 0.2 $\mathrm{ml}$ of an emulsion prepared from the immunogen with an equal volume of complete Freund's adjuvant. Three, 5, 7 and 9 weeks later, the mice were boosted with $0.2 \mathrm{ml}$ of an emulsion prepared from the immunogen with an equal volume of incomplete Freund's adjuvant in the same manner. Five weeks later, i.e., 4 days prior to cell fusion, the mice received the immunogen alone $0.5 \mathrm{mg} / \mathrm{ml}$ in $0.01 \mathrm{M} \mathrm{PB}, 0.2 \mathrm{ml} / \mathrm{mouse}$ ) in the same manner. Splenocytes from the immunized mice were mixed with murine myeloma cells (P3-X63-Ag8.U1) at a ratio of 10:1 and fused by the procedure described by Koehler and Milstein (41) with some modifications.

Selection by hypoxanthine aminopterin thymidine medium (HAT medium) and cloning: The fused cells were cultured in HAT medium and screened with the naked eye for cell growth. The culture media were screened for anti-TTX antibody by enzyme immunoassay (EIA) (described below). Hybridoma cell populations secreting anti-TTX antibody were identified by EIA and cloned by limiting dilution on feeder layers of murine thymocytes.

Amplification and purification of hybridoma proteins: Each cloned hybridoma cell line was grown by tissue culture and amplified in the ascites of pristan (2,6,10,14-tetramethyldecanoic acid)-primed BALB/c mice. Murine IgGcontaining TTX-specific antibodies were purified from the ascites supernatant by affinity chromatography on a proetin A-agarose gel (AmpureTMPA kit, Amersham International, Buckinghamshire, UK) after salting out with 50\% 
saturated $\left(\mathrm{NH}_{4}\right)_{2} \mathrm{SO}_{4}(\mathrm{pH} 7.4)$. Isotyping of the monoclonal antibody was performed with a mouse monolonal antibody isotyping kit (Amersham International, UK).

Preparation of monoclonal antibody-peroxidase conjugate: $\mathrm{F}\left(\mathrm{ab}^{\prime}\right)_{2}$ fragments were prepared by limited proteolysis of purified anti-TTX monoclonal antibody with immobilized pepsin (Sigma). Fab' fragments were prepared by reduction of $\mathrm{F}\left(\mathrm{ab}^{\prime}\right)_{2}$ fragments with cysteamine hydrochloride (Wako). Ten milligrams of peroxidase (EIA grade, Boehringer Mannheim, Germany) was dissolved in 1.5 $\mathrm{ml}$ of $0.1 \mathrm{M}$ phosphate buffer $(\mathrm{pH} 6.0)$. To this was added $0.1 \mathrm{ml}$ of an $N$-(6maleimidocaproyloxy) succinimide (EMCS, Dojin Laboratories, Kumamoto) solution (31 mg of EMCS in $1 \mathrm{ml}$ of dimethylformamide). After incubation for $60 \mathrm{~min}$ at $30 \mathrm{C}$, this mixture was loaded onto a PD-10 column equilibrated with $0.1 \mathrm{M}$ phosphate buffer ( $\mathrm{pH}$ 6.0). The mixture was eluted with $0.1 \mathrm{M}$ phosphate buffer ( $\mathrm{pH}$ 6.0), and the protein-containing portion $(2.0 \mathrm{ml})$ was collected. Fab' fragments $(3.2 \mathrm{mg}$ ) were dissolved in $1.5 \mathrm{ml}$ of $0.1 \mathrm{M}$ phosphate buffer ( $\mathrm{pH} \mathrm{6.0)}$ containing $5 \mathrm{mM}$ EDTA. To this was added $0.6 \mathrm{ml}$ of a modified peroxidase solution $(5 \mathrm{mg} / \mathrm{ml}$ in $0.1 \mathrm{M}$ phosphate buffer, $\mathrm{pH} \mathrm{6.0)}$. After incubation for $60 \mathrm{~min}$ at $30 \mathrm{C}$, conjugates were purified from the mixture by affinity chromatography on concanavalin A-sepharose gel (Pharmacia Biotech.).

In vitro neutralization test: To $1 \mathrm{ml}$ of a TTX solution containing 5 mouse units of TTX, $1 \mathrm{ml}$ each of monoclonal antibody solutions at various concentrations $(0,0.0625,0.125,0.25,0.5$ and $1.0 \mathrm{mg} / \mathrm{ml})$ was added, which was mixed and incubated for $60 \mathrm{~min}$ at $37 \mathrm{C}$. One milliliter of each mixture containing 2.5 mouse units of TTX, which kills a mouse in about $7 \mathrm{~min}$, was administered intraperitoneally to male ddY mice weighing $20 \mathrm{~g}$. The lethality was observed for $24 \mathrm{hr}$ after administration. In this test, one mouse unit is defined as the amount of TTX that kills a male mouse of ddY strain weighing $20 \mathrm{~g}$ in $30 \mathrm{~min}$ after ip injection. Also, Dulbecco's phosphate buffered saline without monoclonal antibody was used as a control.

Procedure and application of EIA: EIA was used to select hybridomas that produced antibodies specific to TTX. TTX-OVA or OVA was diluted in $0.05 \mathrm{M}$ sodium bicarbonate buffer ( $\mathrm{pH} 9.6$ ) to a concentration of $3.0 \mu \mathrm{g} / \mathrm{ml}$, and $0.1 \mathrm{ml}$ of the mixture was added to each well of a 96 -well microtiter plate (Sumitomo Bakelite Co., Ltd., Tokyo). The plate was incubated for $1 \mathrm{hr}$ at room temperature, and the solution was then removed. After washing three times with Dulbecco's phosphate buffered saline (D-PBS) containing $0.05 \%$ Tween 20 (PBS-T), the residual protein-binding sites were blocked with D-PBS containing $20 \%$ horse serum for 60 min at room temperature. The plate was washed three times with PBS-T, and $0.1 \mathrm{ml}$ of a hybridoma supernatant solution diluted with PBS-T containing $10 \%$ horse serum was then added to each well. After incubation for $1 \mathrm{hr}$ at room temperature and washing five times with PBS-T, $0.1 \mathrm{ml}$ of $1: 1,000$ diluted goat antimouse immunogloblin-peroxidase conjugate (Sigma) was added to each well. The plate was then incubated for $1 \mathrm{hr}$ at room temperature and washed three times 
with PBS-T. After washing, $0.1 \mathrm{ml}$ of a substrate solution (described below) was added to each well. After incubation for $10 \mathrm{~min}$ at room temperature, the reaction was stopped with $0.1 \mathrm{ml}$ of $1 \mathrm{~N} \mathrm{H}_{2} \mathrm{SO}_{4}$. The absorbance at $450 \mathrm{~nm}$ of the watersoluble reaction products was measured with a microplate-auto reader (Model 550, Japan-Biorad, Tokyo).

The substrate solution was prepared, just before use, by mixing $0.1 \mathrm{ml}$ of a 3,3'5,5'-tetramethylbenzidine (TMBZ, Dojin) solution (10 mg of TMBZ in $1 \mathrm{ml}$ of dimethyl-formamide) and $1.5 \mu \mathrm{l}$ of $30 \%$ hydrogen peroxide in $9.9 \mathrm{ml}$ of $0.05 \mathrm{M}$ citrate buffer ( $\mathrm{pH}$ 5.5).

Procedure and application of competitive EIA: This assay was used to determine quantitatively TTX and examine the specificity of the monoclonal antibody against TTX. Antigen-coated plates were prepared in the same manner as described in the EIA procedure. After washing, $0.1 \mathrm{ml}$ of TTX standard of increasing concentrations $(0-200 \mathrm{ng} / \mathrm{ml})$ or each sample was added to each well, followed by $0.05 \mathrm{ml}$ of monoclonal antibody-peroxidase conjugates (Fab' fragments) at 0.26 $\mu \mathrm{g} / \mathrm{ml}$ diluted with phosphate buffered saline $(0.03 \mathrm{M}$ phosphate buffer, $\mathrm{pH} 7.4$; $0.41 \mathrm{M} \mathrm{NaCl}, 8 \mathrm{mM} \mathrm{KCl}$ ), and the contents of the well were immediately mixed. After incubation for $20 \mathrm{~min}$ at room temperature and washing five times with PBS-T, the substarate solution was added to each well. The following steps in the competitive EIA were performed as described in the EIA procedure. The amount of antibody bound to the solid-phase antigen (coated on the plate) was calculated as follows: the absorbance values obtained for TTX standards or samples were divided by the absorbance value of $0 \mathrm{ng} / \mathrm{ml}$ of the TTX standard (see below) and multiplied by 100 .

Preparation of TTX standards for competitive EIA: First, TTX $(0.1 \mathrm{mg} / \mathrm{ml})$ was adjusted to various concentrations $(5,10,25,50,100,250,500$ and 1,000 $\mathrm{ng} / \mathrm{ml}$ ) in $0.1 \%$ acetic acid. The solutions were diluted five-fold with distilled water and then used as TTX standards (final concentrations of TTX standards were $1,2,5,10,20,50,100$ and $200 \mathrm{ng} / \mathrm{ml}$ ). A $0.02 \%$ acetic acid solution was used as a control of the TTX standard $(0 \mathrm{ng} / \mathrm{ml})$.

Specificity of the monoclanal antibody against TTX: The specificity of the monoclonal antibody against TTX was examined by comparing the concentration of each toxin (TTX, tetrodonic acid, anhydro-terodotoxin or gonyautoxins) that causes $50 \%$ inhibition of binding of the antibody to the solid-phase antigen in the competitive EIA. Tetrodonic acid and anhydro-terodotoxin, which are TTX derivatives, were synthesized from TTX by the method of Tsuda et al (42). Gonyautoxins, which were a mixture of gonyautoxin I, II, III and IV, were purchased from Wako.

Mouse bioassay: Mouse bioassay was performed by the method of Kawabata (25). One mouse unit is defined as the amount of TTX that kills a male mouse of ddY strain weighing $20 \mathrm{~g}$ in $30 \mathrm{~min}$ and is equivalent to $220 \mathrm{ng}$ of TTX. To compare the mouse bioassay with the competitive EIA, the results of the bioassay were expressed in the TTX content. 
Preparation of sample: Samples from the muscles of puffer fish were prepared by the $0.1 \%$ acetic acid extraction-method (25). To $10 \mathrm{~g}$ of homogenized puffer fish muscle, $25 \mathrm{ml}$ of $0.1 \%$ acetic acid was added. The mixture was boiled and stirred for $10 \mathrm{~min}$. The extract was cooled and centrifuged at 3,000 rpm for 15 min at $4 \mathrm{C}$. After collecting the supernatant, aliquots $(15 \mathrm{ml})$ of $0.1 \%$ acetic acid were again added to the remaining precipitates. The mixture was then stirred and centrifuged to collect the supernatant. Two supernatants were combined and then filled to $50 \mathrm{ml}$ with $0.1 \%$ acetic acid. This solution was used for the mouse bioassay. For the competitive EIA, this solution was diluted five-fold with distilled water. When the smaples contained a high level of TTX, these were diluted more than five-fold.

Recovery tests and examinations of TTX samples from puffer fish: To compare the competitive EIA with the mouse bioassay, recovery tests and examinations of TTX samples were carried out. In recovery tests, different quantities (2.5, $5,10$ and $20 \mu \mathrm{g})$ of TTX were injected into the muscles $(10 \mathrm{~g})$ of three species of puffer fish (Takifugu rubripes, Takifugu xanthopterus and Lagocephalus wheeleri). After keeping for $30 \mathrm{~min}$ at room temperature, concentrations of TTX in the muscles were estimated by the mouse bioassay and the competitive EIA. In examinations of TTX samples, the muscles of naturally contaminated puffer fish (six Takifugu poecilonotus and seven Lagocephalus lunaris) were used. Concentrations of TTX in the muscles were estimated by the mouse bioassay and the competitive EIA, and the results obtained by the mouse bioassay were plotted against those by the competitive EIA.

Takifugu rubripes, a cultured puffer fish, was purchased from a seafood store. Takifugu xanthopterus, Lagocephalus wheeleri and Takifugu poecilonotus were captured offshore Ikitsukishima Island in Nagasaki Prefecture. Lagocephalus lunaris was provided by Osaka Quarantine Station, Ministry of Health and Welfare.

\section{RESULTS}

Production and Specificity of Monoclonal Antibody against TTX

Because TTX, a hapten, has no immunogenicity, TTX-BSA conjugate was synthesized for the immunization of mice. The other hapten-protein conjugate, TTX-OVA, was synthesized for EIA. For selection of specific antibody-secreting hybridomas, the protein carrier used for EIA must be different from that for mice immunization. The antibodies to the protein carrier were not reactive in EIA. Five culture supernatants in 180 wells of the tissue culture plates showed positive results in EIA (2.8\%). Clear competition in the competitive EIA was observed in 
Table I. Specificity of the monoclonal antibody against tetrodotoxin

\begin{tabular}{llc}
\hline $\begin{array}{l}\text { Toxin } \\
\text { (mol.wt.) }\end{array}$ & Concentration of $50 \%$ inhibition & Cross-reactivity \% \\
\hline $\begin{array}{l}\text { Tetrodotoxin } \\
(319)\end{array}$ & $\begin{array}{l}0.05 \mathrm{nmol} / \mathrm{ml} \\
(15 \mathrm{ng} / \mathrm{ml})\end{array}$ & 100 \\
$\begin{array}{l}\text { Anhydro- } \\
\text { tetrodotoxin }\end{array}$ & $0.60 \mathrm{nmol} / \mathrm{ml}$ \\
$(301)$ & $(180 \mathrm{ng} / \mathrm{ml})$ & 8.3 \\
$\begin{array}{l}\text { Tetrodonic acid } \\
(337)\end{array}$ & $>0.30 \mu \mathrm{mol} / \mathrm{ml}$ & \\
Gonyautoxins & $(>100 \mu \mathrm{g} / \mathrm{ml})$ & $<0.017$ \\
\hline
\end{tabular}

The specificity of the monoclonal antibody against TTX was examined by comparing the concentration of each toxin that caused $50 \%$ inhibition of binding of the antibody to solid-phase antigen in the competitive EIA. Gonyautoxins are a mixture of gonyautoxin I, II, III and IV.

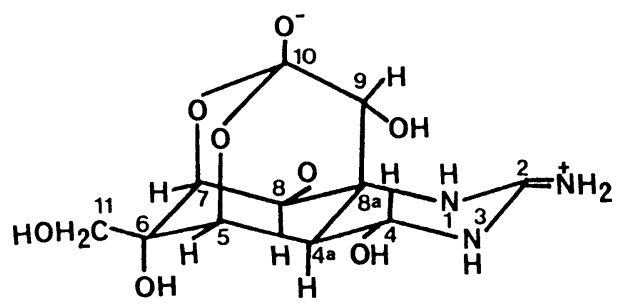

(a) Tetrodotoxin

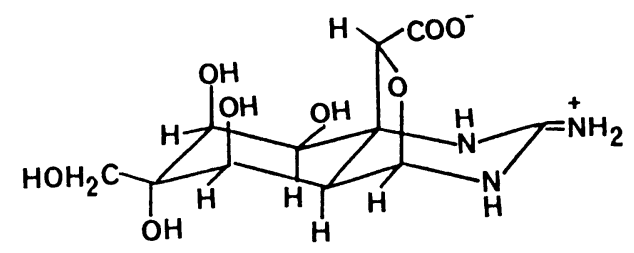

(c) Tetrodonic acid

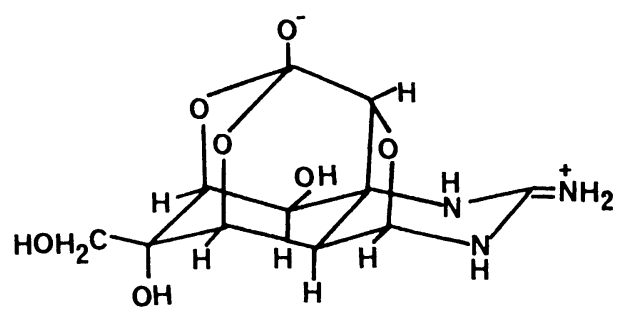

(b) Anhydro-tetrodotoxin

Fig. 1. The chemical structures of tetrodotoxin, anhydro-tetrodotoxin and tetrodonic acid. 
Table II. In vitro neutralizing activity of the monoclonal antibody to the lethality of tetrodotoxin

\begin{tabular}{lcc}
\hline $\begin{array}{l}\text { Monoclonal antibody } \\
\text { concentration }(\mathrm{mg} / \mathrm{ml})\end{array}$ & Survival/Total & \% Survival \\
\hline 1.0 & $5 / 5$ & 100 \\
0.5 & $5 / 5$ & 100 \\
0.25 & $5 / 5$ & 100 \\
0.125 & $2 / 5$ & 40 \\
0.0625 & $0 / 5$ & 0 \\
0 & $0 / 5$ & 0 \\
\hline
\end{tabular}

To $1 \mathrm{ml}$ of a TTX solution containing 5 mouse units of TTX, $1 \mathrm{ml}$ of a monoclonal antibody solution of various concentrations $(0,0.0625,0.125$, $0.25,0.5$ and $1.0 \mathrm{mg} / \mathrm{ml}$ ) was added and the mixture was incubated for $60 \mathrm{~min}$ at $37 \mathrm{C}$. One milliliter of the mixture (containing 2.5 mouse units) was administered intraperitoneally to each of five male ddY mice weighing $20 \mathrm{~g}$. The lethality was determined $24 \mathrm{hr}$ after administration. One mouse unit is defined as the amount of TTX that kills a male mouse of ddY weighing $20 \mathrm{~g}$ in 30 min after ip injection.

two of the five wells by using $5 \mathrm{ng}$ of TTX per assay. Each hybridoma-secreting anti-TTX antibody was cloned three times by the limiting dilution method, and two cloned hybridoma cell lines (T1-1 and T2-1) were obtained. The clone (T1-1) that showed the highest affinity to free TTX was selected and used in this study. The class of heavy and light chains of the monoclonal antibody were IgG1 and $\mathrm{k}$, respectively. The specificity of the monoclonal antibody against TTX is shown in Table I. The monoclonal antibody had no cross-reaction to tetrodonic acid, whose chemical structure is shown in Fig. 1 (c), or gonyautoxins under the experimental condition $(<0.017 \%)$. However, the antibody had only a minor cross-reaction to anhydro-teterodotoxin, which is very similar in chemical structure to TTX, as shown in Fig. 1 (b) (8.3\%). However, affinity between the antibody and anhydrotetrodotoxin was lower than one-tenth of that between the antibody and TTX. 
Table III. Reproducibility of standard curve for tetrodotoxin in the competitive EIA

\begin{tabular}{llll}
\hline & $\begin{array}{c}\text { TTX standard } \\
(\mathrm{ng} / \mathrm{ml})\end{array}$ & \multicolumn{2}{c}{ Antibody binding (\%) } \\
\cline { 3 - 4 } & 2 & Mean $\pm \mathrm{SD}$ & $\mathrm{CV}(\%)$ \\
\hline 5 & $85.0 \pm 2.3$ & 2.7 \\
intra-assay & 10 & $74.1 \pm 2.4$ & 3.2 \\
& 20 & $55.7 \pm 1.9$ & 3.4 \\
50 & $43.9 \pm 1.8$ & 4.1 \\
& 100 & $25.6 \pm 2.4$ & 9.4 \\
& 2 & $12.8 \pm 1.2$ & 9.4 \\
\hline 5 & $86.2 \pm 1.2$ & 1.4 \\
inter-assay & 10 & $75.5 \pm 1.2$ & 1.6 \\
20 & $57.0 \pm 1.3$ & 2.3 \\
50 & $45.1 \pm 1.4$ & 3.1 \\
100 & $26.5 \pm 1.4$ & 5.3 \\
& $14.1 \pm 1.5$ & 10.6 \\
\hline
\end{tabular}

Antibody binding (\%); see Fig. 2. Each antibody binding (\%) of intraassay represents the mean of six assays, and each antibody binding (\%) of inter-assay represents the mean of triplicate assays. SD and CV represent standard deviation and coefficient of variation, respectively.

\section{In Vitro Neutralization Test}

The results of the neutralization test are shown in Table II. The mice injected with a mixture of a TTX solution and PBS or an antibody solution at a low concentration $(0.0625 \mathrm{mg} / \mathrm{ml})$ all died. In contrast, the mice injected with a mixture of TTX solution and an antibody solutions at a high concentration $(0.125$, $0.25,0.5$ or $1.0 \mathrm{mg} / \mathrm{ml}$ ) showed from 40 to $100 \%$ survival. These results showed that the monoclonal antibody neutralized the lethal activity of TTX.

\section{Competitive EIA}

Figure 2 and Table III show standard curves for TTX in the competitive EIA and its reproducibility, respectively. The absorbance values obtained for $0 \mathrm{ng} / \mathrm{ml}$ 


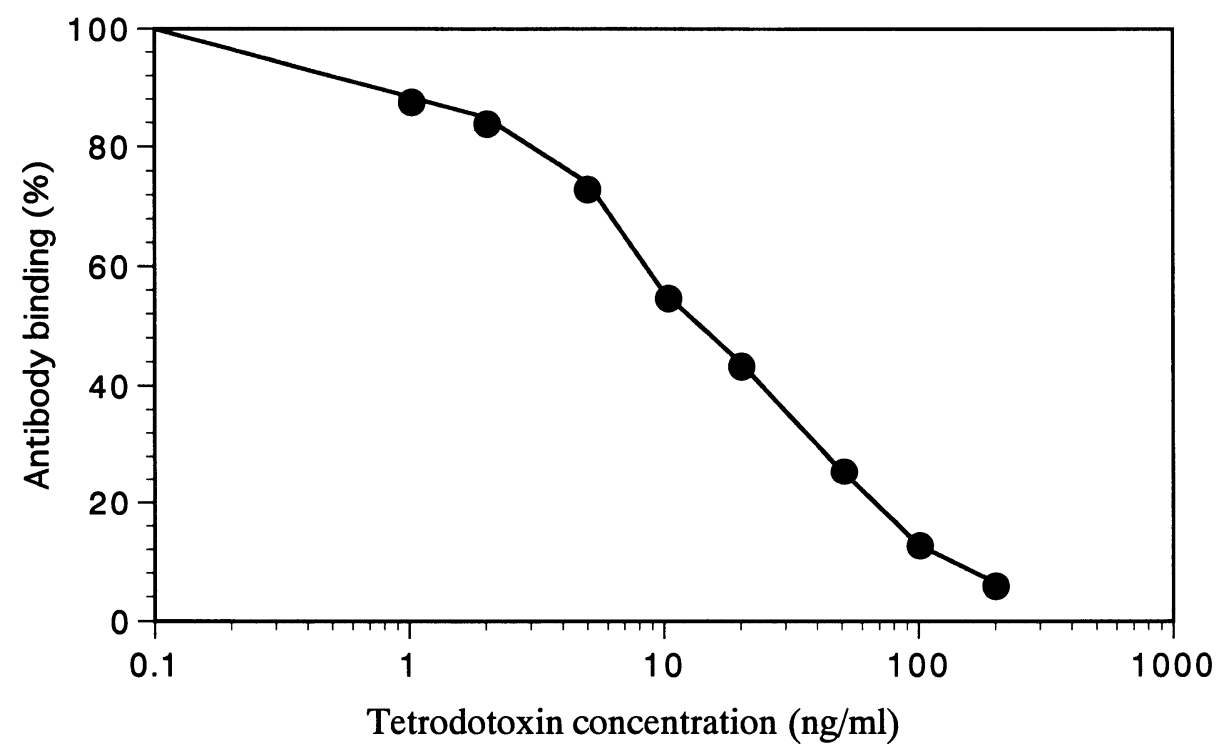

Fig. 2. Standard curve for tetrodotoxin in competitive EIA. Microtiter wells coated with TTX-OVA were incubated with increasing concentrations of TTX standards $(0,1,2,5,10,20,50,100$ and $200 \mathrm{ng} / \mathrm{ml})$ in the presence of a constant amount of monoclonal antibody-peroxidase conjugate $(0.26 \mu \mathrm{g} / \mathrm{ml})$. Antibody binding (\%) was calculated as follows: the absorbance values obtained for TTX standards were divided by the absorbance value of $0 \mathrm{ng} / \mathrm{ml}$ of TTX standard and multiplied by 100 . Each point represents the mean of six assays.

of TTX standard ranged from 1.60 to 1.70 . Linearity of the standard curve for TTX was observed from 2 to $100 \mathrm{ng} / \mathrm{ml}$ (Fig. 2). The standard curves for TTX had good reproducibility in a range from 2 to $100 \mathrm{ng} / \mathrm{ml}$ since the intra-assay and inter-assay coefficients of variation were less than 9.4 and $10.6 \%$, respectively (Table III). In the competitive EIA, the concentration of toxin causing $10-20 \%$ inhibition of binding of the antibody to the solid-phase antigen is generally established as the detection limit of the assay $(31,32,34)$. Therefore, the detection limit for TTX in the competitive EIA was established at $2 \mathrm{ng} / \mathrm{ml}$. The results shown in Fig. 2 and Table III show the working range for quantitative analysis of TTX in the competitive EIA being $2-100 \mathrm{ng} / \mathrm{ml}$. When a sample was prepared by the $0.1 \%$ acetic acid-extraction method, the detection limit for TTX in the competitive EIA was regarded as $50 \mathrm{ng} / \mathrm{g}$ of the original sample in the calculation. 
Table IV. Recovery tests of tetrodotoxin in muscles of puffer fish

\begin{tabular}{lccc}
\hline \multirow{2}{*}{$\begin{array}{l}\text { Detection } \\
\text { method }\end{array}$} & $\begin{array}{c}\text { Toxin injected } \\
(\mathrm{ng} / \mathrm{g})\end{array}$ & \multicolumn{2}{c}{ Determination value (ng/g) } \\
\cline { 3 - 4 } & & Mean $\pm \mathrm{SD}$ & $\mathrm{CV}(\%)$ \\
\hline & 0 & $<50$ & - \\
& 250 & $251 \pm 39.8$ & 15.9 \\
Competitive & 500 & $485 \pm 35.0$ & 7.2 \\
EIA & 1000 & $1025 \pm 115.5$ & 11.3 \\
& 2000 & $2042 \pm 167.8$ & 8.2 \\
\hline & 0 & $\mathrm{ND}$ & - \\
Mouse bioassay & 250 & $\mathrm{ND}$ & - \\
& 500 & $\mathrm{ND}$ & - \\
& 1000 & $\mathrm{ND}$ & - \\
& 2000 & $1962 \pm 148.0$ & 7.5 \\
\hline
\end{tabular}

Different quantities $(2.5,5,10$ and $20 \mu \mathrm{g})$ of TTX were injected into muscles $(10 \mathrm{~g})$ of three species of puffer fish, and then extracted by the $0.1 \%$ acetic acid extraction-method. Concentrations of TTX in the samples were estimated by the mouse bioassay and the competitive EIA. When the $0.1 \%$ acetic acid extraction-method was used, the detection limits of the competitive EIA and the mouse bioassay were 50 and $1100 \mathrm{ng} / \mathrm{g}$ of the original sample, respectively. Each determination value represents the mean of three experiments. SD and CV represent standard deviation and coefficient of variation, respectively. ND is not detectable.

\section{Recovery Tests and Examinations of TTX Samples from Puffer Fish}

Table IV shows the results of recovery tests. When the $0.1 \%$ acetic acid extraction-method was used, final concentrations of TTX injected in the extracts were $0,50,100,200$ and $400 \mathrm{ng} / \mathrm{ml}$. Therefore, by the mouse bioassay, whose detection limit was $220 \mathrm{ng} / \mathrm{ml}$, ranges from 250 to $1,000(\mathrm{ng} / \mathrm{g})$ of TTX injected were not detected. In contrast, by using the competitive EIA, all ranges of TTX injected were precisely determined (coefficients of variation for determination values in three experiments were less than 15.9\%). These results showed that such low concentrations of TTX that could not be detected by the mouse bioassay, were 


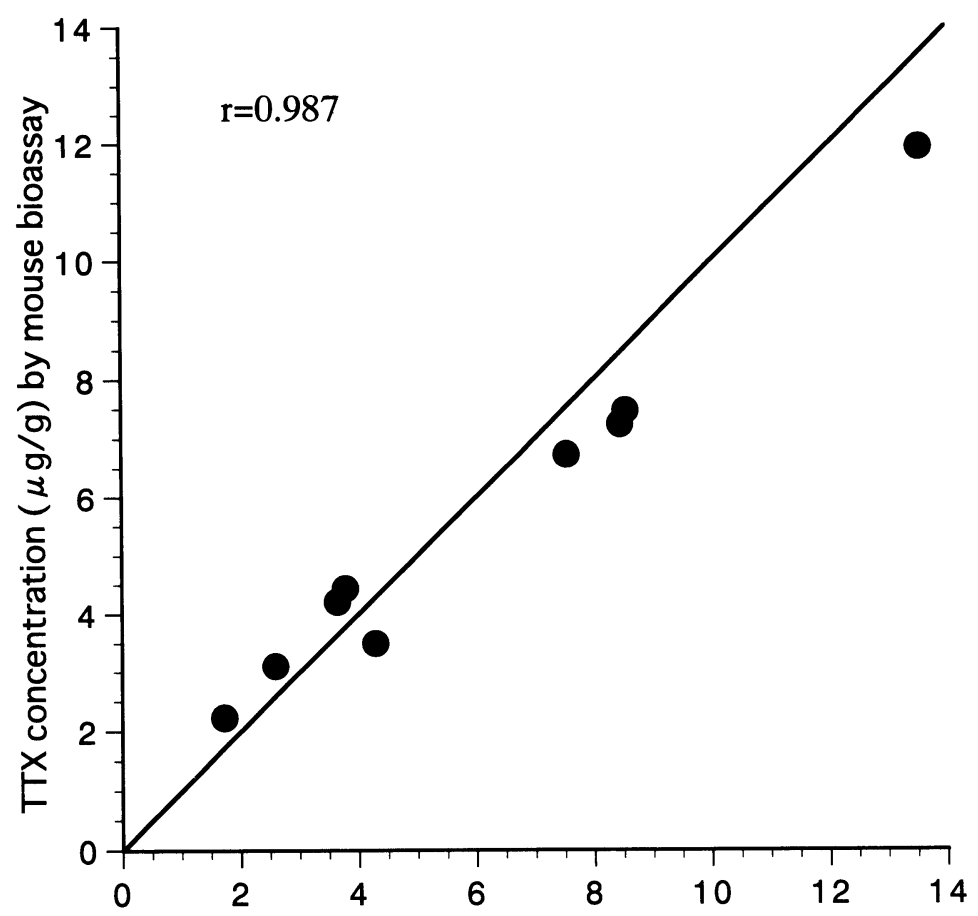

Fig. 3. Correlation of results for TTX obtained by the mouse bioassay and by the competitive EIA $(n=9)$. In examination of the muscles from naturally contaminated puffer fish (six Takifugu peocilonotus and seven Lagocephalus lunaris), the results of the mouse bioassay were plotted against the results of the competitive EIA. To compare the mouse bioassay with the competitive EIA, the results of the mouse bioassay were expressed as TTX content (one mouse unit is equivalent to $220 \mathrm{ng}$ of TTX). Four samples of Takifugu poecilonotus gave positive results only by the competitive EIA. TTX concentrations of the samples estimated by the competitive EIA were $0.25,0.31,0.56$ and $0.59 \mu \mathrm{g} / \mathrm{g}$, respectively.

determined quantitatively by the competitive EIA. Figure 3 shows correlations of TTX determinations by the competitive EIA and the mouse bioassay. An excellent correlation was observed between the results of the mouse bioassay and EIA analyses $(r=0.987)$. 


\section{DISCUSSION}

Initially, we attempted to improve the preparation method of immunogen to obtain a monoclonal antibody with a high specificity against TTX. In previous studies, TTX-KLH conjugate was used as an immunogen $(37,38)$. However, there was a report stating that it was difficult to produce the antibody with a high affinity for TTX in mice immunized with TTX-KLH conjugate (39). Actually, the antibody obtained from the mice immunized with TTX-KLH conjugate prepared in our preliminary study had no reaction to free TTX (data not shown). Therefore, in this study, TTX-BSA conjugate was used as an immunogen to produce the antibody against TTX. In addition, in this study, an immunogen binding a larger quantity of TTX than that in the previous studies $(37,38)$ was used for the immunization. It appears that the application of this immunogen is one of the reasons why we succeeded to obtain a monoclonal antibody with a high specificity against TTX. TTX (Fig. 1, a) an $\mathrm{Na}+$ channel blocker, shows toxicity by attaching to an $\mathrm{Na}+$ channel with three points of the guanidinium group and the hydroxyls at $\mathrm{C} 9$ and $\mathrm{C} 10$ (1). Anhydro-tetrodotoxin (Fig. 1, b), in which C4-OH and $\mathrm{C} 9-\mathrm{OH}$ are joined by an oxygen bridge, has a low affinity to the $\mathrm{Na}+$ channel and little toxicity (toxicity is at least a 100 times less than that of TTX) $(1,2,4,42)$. Tetrodonic acid (Fig. 1, c), in which both $\mathrm{C} 9-\mathrm{OH}$ and $\mathrm{C} 10-\mathrm{OH}$ are modified, has neither affinity to the $\mathrm{Na}+$ channel nor the toxicity $(1,2,4,42)$. The monoclonal antibody produced in this study had only a minor cross-reaction to anhydrotetrodotoxin, but had no cross-reaction to tetrodonic acid (Table I). In addition, this antibody neutralized the toxicity of TTX (Table II). The guanidinium group was used as a site to conjugate TTX to protein in this study (40). Therefore, it is regarded that this antibody reacts with the $\mathrm{C} 9-\mathrm{OH}$ and $\mathrm{C} 10-\mathrm{OH}$ of TTX as in the previous study (38). The antibody in the previous study also had only a minor cross-reaction to tetrodonic acid except for anhydro-tetrodotoxin (38). Consequently, this antibody is more specific against TTX than that in the previous study.

Next, using this monoclonal antibody, we attempted to develop a rapid and highly sensitive competitive EIA system for quantitative analysis of TTX. The EIA system for TTX reported previously had an extremely low sensitivity because an antibody against tetrodonic acid, a TTX derivative, was used (36). More recently, the EIA system reported by Matsumura et al. $(37,38)$ had a high sensitivity, but required a long time to determine TTX since the avidin-biotin system was used to improve a sensitivity of the assay. In contrast, the EIA system developed 
in this study had a sufficient sensitivity without the avidin-biotin system, since the antibody with high affinity against TTX was used (the working range for the quantitative analysis of TTX was $2-100 \mathrm{ng} / \mathrm{ml}$ ). In addition, the extra steps in the assay could be omitted by use of the antibody-peroxidase conjugate. Therefore, in the EIA system developed in this study, TTX could be determined quantitatively and sensitively in about $30 \mathrm{~min}$ (90 min was required if the time for preparation of the solid-phase antigen is included). If this EIA system is used, a rapid response to an outbreak of food poisoning and the determination of small amounts of TTX in leftovers will be possible. Moreover, this EIA system, which uses the antibody that had no or minor cross-reaction to TTX derivatives, is useful to determine the exact toxicity of puffer fish, since other TTX derivatives found in puffer fish show no or slight toxicity $(42,43)$. The toxicity of puffer fish is different depending on the organ and species, and the consumption of the muscles of 21 species, the skins of 11 species and the tests of 18 species of puffer fish are allowed in Japan. Puffer fish whole are generally marketed, but the muscles, the skins and the tests of puffer fish have often been marketed separately. In the latter case, it is very difficult to identify the toxicity by morphological features. Therefore, it is necessary to monitor closely TTX in seafoods derived from puffer fish. At present, the methods for monitoring TTX are mainly mouse bioassay and fluorometric HPLC (25-28). The mouse bioassay is the official method (25), and TTX can be simply determined in a short time by the bioassay; however, the bioassay has a low sensitivity (its detection limit is $220 \mathrm{ng} / \mathrm{ml}$ ) (25). In this study, four samples of Takifugu poecilonotus were negative in the mouse bioassay, while they were positive in the competitive EIA (Fig. 3). It has recently been reported that a small amount of TTX, which could not be detected by the mouse bioassay, was found in a cultured puffer fish which originally was nontoxic (24). Therefore, it is considered that TTX in the samples must be monitored by a more sensitive method than the mouse bioassay. The fluorometric HPLC is highly sensitive (26-28), but not sufficiently specific (29). In addition, this method requires cleanup of samples and very expensive instruments (27). For the above reasons, it appears that the newly developed EIA system is more useful for the rapid and sensitive monitoring of TTX in seafoods derived from puffer fish and other marine products than the mouse bioassay or the fluorometric HPLC.

It is considered that TTX is originally produced by bacteria, and there are many reports on TTX-producing bacteria (17-23). However, reexamination of possible TTX-producing bacteria is necessary because the existence of such bacteria is being challenged (29). For such studies, it is thought that the antibody ob- 
tained in this study would extremely be useful. Moreover, this antibody with a high specificity to TTX can be used widely in TTX-related studies.

\section{ACKNOWLEDGMENTS}

We thank Mr. S. Itoh, Osaka Quarantine Station, and Mr. H. Kozuka for providing puffer fish.

\section{REFERENCES}

1. Lipkind, G. M. and Fozzard, H. A. (1994): A structural model of the tetrodotoxin and saxitoxin binding site of the $\mathrm{Na}+$ channel. Biophys. J., 66, $1-13$.

2. Narahasi, T., Moore, J. W. and Poston, R. N. (1967): Tetrodotoxin derivatives: Chemical structure and blockage of nerve membrane conductance. Science, 156, 976-978.

3. Goto, T., Kishi, Y., Takahashi, S. and Hirata, Y. (1965): Tetrodotoxin. Tetrahedron, 21, 2059-2088.

4. Kao, C. Y. (1966): Tetrodotoxin, saxitoxin and their significance in the study of excitation phenomena. Pharmacol. Rev., 18, 997-1048.

5. Shiomi, K., Inaoka, H., Yamanaka, H. and Kikuchi, T. (1985): Detection of tetrodotoxin-like compounds in two species of puffer fish (Lagocephalus lunaris lunaris and Fugu niphobles). Toxicon, 23, 331-336.

6. Kao, C. Y. and Fuhrman, F. A. (1964): Identity of tarichatoxin and tetrodotoxin. Science, 143, 474-475.

7. Kim, Y. H., Brown, G. B. and Mosher, H. S. (1975): Tetrodotoxin: Occurrence in atelopid frogs of Costa Rica. Science, 189, 151-152.

8. Kungsuwan, A., Nagashima, Y., Noguchi, T., Shida, Y., Suvapeepan, S., Suwansakorhkul, P. and Hashimoto, K. (1987): Tetrodotoxin in the horseshoe crab Carcinoscorpius rotundicauda inhabiting Thailand. Bull. Jpn. Soc. Sci. Fish., 53, 261-266.

9. Noguchi, T. and Hashimoto, Y. (1973): Isolation of tetrodotoxin from a goby Gobius criniger. Toxicon, 11, 305-307.

10. Noguchi, T., Narita, H., Maruyama, J. and Hashimoto, K. (1982): Tetrodotoxin in the starfish Astrospecten polyacanthus, in association with toxification of a trumpet shell, "Boshubora" Charonia sauliae. Bull. Jpn. Soc. Sci. Fish., 48, 1173-1177.

11. Sheumack, D. D. and Howden, M. E. H. (1978): Maculotoxin: A neurotoxin from the venom glands of the octopus Hapalochlaena maculosa identified as teterodotoxin. Science, 199, 188-189. 
12. Narita, H., Noguchi, T., Maruyama, J., Ueda, Y., Hashimoto, K., Watanabe, Y. and Hida, K. (1981): Occurrence of tetrodotoxin in a trumpet shell, "Boshubora" Charonia sauliae. Bull. Jpn. Soc. Sci. Fish., 47, 935-941.

13. Noguchi, T., Jeon, J. K., Maruyama, J., Sato, Y., Saisho, T. and Hashimoto, K. (1985): Toxicity of trumpet shells inhabiting the coastal waters of Kagoshima Prefecture, along with identification of the responsible toxin. Bull. Jpn. Soc. Sci. Fish., 51, 1727-1731.

14. Yasumoto, T., Oshima, Y., Hosaka, M. and Miyakoshi, S. (1981): Occurrence of tetrodotoxin in the ivory shell Babylonia japonica from Wakasa bay. Bull. Jpn. Soc. Sci. Fish., 47, 929-934.

15. Hamano, Y., Kumeda, Y., Yamamoto, H., Otsu, K., Kinoshita, Y., Nozaki, S., Tomioka, K., Umeda, A., Furukawa, K., Tonomoto, M., Kobayashi, K., Senda, A. and Takemura, Y. (1987): Studies on fish and shellfish toxins (7th report) - Fugu poisoning outbroken in Osaka in 1986-. Proceedings of Osaka Prefectural Institute of Public Health. Ed. of Food Sanitation, 18, 1-5 (in Japanese).

16. Hamano, Y., Kawatsu, K., Yoda, T., Shibata, T. and Sasaki, Y. (1996): Food poisoning incidents caused by marine toxins in 1985 to 1993. Proceedings of Osaka Prefectural Institute of Public Health. Ed. of Food Sanitation, 27, 3943 (in Japanese).

17. Do, H. K., Kogure, K. and Simidu, U. (1990): Identification of deep-seasediment bacteria which produce tetrodotoxin. Appl. Environ. Microbiol., 56, 1162-1163.

18. Kungsuwan, A., Noguchi, T., Arakawa, O., Simidu, U., Tsukamoto, K., Shida, Y. and Hashimoto, K. (1988): Tetrodotoxin-producing bacteria from the horseshoe crab Carcinoscorpius rotundicauda. Bull. Jpn. Soc. Sci. Fish., 54, 1799-1802.

19. Narita, H., Matsubara, S., Miwa, N., Akahane, S., Murakami, M., Goto, T., Nara, M., Noguchi, T., Saito, T., Shida, Y. and Hashimoto, K. (1987): Vibrio alginolyticus, a TTX-producing bacterium isolated from the starfish Astropecten polyacanthus. Bull. Jpn. Soc. Sci. Fish., 53, 617-621.

20. Noguchi, T., Jeon, J. K., Arakawa, O., Sugita, H., Deguchi, Y., Shida, Y. and Hashimoto, K. (1986): Occurrence of tetrodotoxin and anhydrotetrodotoxin in Vibrio sp. isolated from the intestines of a xanthid crab, Atergatis floridus. J. Biochem., 99, 311-314.

21. Noguchi, T., Hwang, D. F., Arakawa, O., Sugita, H., Deguchi, Y., Shida, Y. and Hashimoto, K. (1987): Vibrio alginolyticus, a tetrodotoxin-producing bacterium, in the intestines of the fish Fugu vermicularis vemicularis. Marine Biol., 94, 625-630.

22. Simidu, U., Noguchi, T., Hwang, D. F., Shida, Y. and Hashimoto, K. (1987): Marine bacteria which prodcue tetrodotoxin. Appl. Environ. Microbiol., 53, 1714-1715. 
23. Yotsu, M., Yamazaki, T., Meguro, Y., Endo, A., Murata, M., Naoki, H. and Yasumoto, T. (1987): Production of tetrodotoxin and its derivatives by Pseudomonas sp. isolated from the skin of a pufferfish. Toxicon, 25, 225-228.

24. Matsumura, K. (1996): Tetrodotoxin concentrations in cultured puffer fish, Fugu rbripes. J. Agric. Food Chem., 44, 1-2.

25. Kawabata, T. (1978): Assay method for tetrodotoxin. In Food Hygiene Examination manual, vol. II, Environmental Health Bureau, Jpn Food Hygiene Association. Tokyo, Japan, p. 232-240 (in Japanese).

26. Nagasima, Y., Maruyama, J., Noguchi, T. and Hashimoto, K. (1987): Analysis of paralytic shellfish poison and tetrodotoxin by ion-pairing performance liquid chromatography. Bull. Jpn. Soc. Sci. Fish., 53, 819-823.

27. Yasumoto, T. and Michishita, T. (1985): Fluorometric determination of tetrodotoxin by high performance liquid chromatography. Agric. Biol. Chem., 49, 3077-3080.

28. Yasumoto, T., Fukui, M., Sasaki, K. and Sugiyama, K. (1995): Determinations of marine toxins in foods. J. AOAC Int., 78, 574-582.

29. Matsumura, K. (1995): Reexamination of tetrodotoxin production by bacteria. Appl. Environ. Microbiol., 61, 3468-3470.

30. Chin, J. D., Quilliam, M. A., Fremy, J. M., Mohapatra, S. K. and Sikorska, H. M. (1995): Screening for okadaic acid by immunoassay. J. AOAC Int., 78, 508-513.

31. Chu, F. S. and Fan, T. S. L. (1985): Indirect enzyme-linked immunosorbent assay for saxitoxin in shellfish. J. AOAC Int., 68, 13-16.

32. Chu, F. S. and Huang, X. (1992): Production and characterization of antibodies against neosaxitoxin. J. AOAC Int., 75, 341-345.

33. Hamano, Y. (1990): Studies on diarrhetic shellfish toxins, particularly okadaic acid. Med. J. Osaka Univ., 43, 67-81 (in Japanese).

34. Usagawa, T., Nishimura, M., Itoh, Y., Uda, T. and Yasumoto, T. (1989): Preparation of monoclonal antibodies against okadaic acid prepared from the sponge Halichondria okadai. Toxicon, 27, 1323-1330.

35. Usleber, E., Dietrich, R., Martlbauer, E. and Terplan, G. (1994): Effect of heterologous paralytic shellfish poisoning toxin-enzyme conjugates on the cross-reactivity of saxitoxin enzyme immunoassay. Lett. Appl. Microbiol., 18, 337-339.

36. Watabe, S., Sata, Y., Nakaya, M., Hashimoto, K., Enomoto, A., Kaminogawa, S. and Yamauchi, K. (1989): Monoclonal antibody raised against tetrodonic acid, a derivative of tetrodotoxin. Toxicon, 27, 265-268.

37. Matsumura, K. and Fukiya, S. (1992): Indirect competitive enzyme immunoassay for tetrodotoxin using a biotin-avidin system. J. AOAC Int., 75, 883-886.

38. Matsumura, K. (1995): A monoclonal antibody against tetrodotoxin that reacts to the active group for toxicity. Eur. J. Pharmacol., 293, 41-45.

39. Watabe, S. (1988): Recent Advances in Tetrodotoxin Research. K. Hashimoto (ed.), Jpn. Soc. Sci. Fish., Tokyo, Japan, p.21-31. (in Japanese). 
40. Johnson, H. M., Frey, P. A., Angelotti, R., Campbell, J. E. and Lewis, K. H. (1964): Haptenic properties of paralytic shellfish poison conjugated to proteins by formaldehyde treatment. Proc. Soc. Exp. Biol. Med., 117, 425-430.

41. Koehler, G. and Milstein, C. (1975): Continuous cultures of fused cells secreting antibody of predefined specificity. Nature, 256, 495-497.

42. Tsuda, K., Ikuma, S., Kawamura, M., Tachikawa, R., Sakai, K., Tamura, C. and Amakatsu, O. (1964): Tetrodotoxin VII. On the structure of tetrodotoxin and its derivatives. Chem. Pharmacol. Bull., 12, 1357-1374.

43. Nakamura, M. and Yasumoto, T. (1985): Tetrodotoxin derivatives in puffer fish. Toxicon, 23, 271-276. 